\title{
Effects of Various Kinds of Salt on the Quality and Storage Characteristics of Tteokgalbi
}

\author{
Hyun-Joo Lee ${ }^{1}$ and Jae-Joon Lee* \\ Department of Food and Nutrition, Chosun University, Gwangju 500-759, Korea \\ ${ }^{1}$ Department of Nutrition and Culinary Science, Hankyong National University, Ansung 56-749, Korea
}

\begin{abstract}
This study was carried out to evaluate the effects of various kinds of salt on the quality and storage characteristics of tteokgalbi. The tteokgalbi was prepared using four types of salt: $1.5 \%$ purified salt (control, C), $1.5 \%$ five-year-old solar salt (FS), 1.5\% Topan solar salt (TS), and 1.5\% French Guérande solar salt (GS). The moisture, crude lipid, crude ash, crude protein and calorie contents, water holding capacity, and cooking loss were not significantly different between control and all other treatments. As for the textural characteristics, the use of GS increased the hardness of the tteokgalbi. According to the sensory evaluation, the use of TS had the best score in springiness. Tteokgalbi made with TS and GS had the two highest scores in flavor and total acceptability. During $15 \mathrm{~d}$ of storage, the contents of 2-thiobarbituric acid (TBA) value, volatile basic nitrogen (VBN) and the total microbial counts increased, while the $\mathrm{pH}$ decreased. The TBA values of the tteokgalbi containing TS and GS were lower than that of C. Lightness $(L)$ and yellowness $(b)$ values decreased during storage, but redness (a) displayed no significant difference during storage. Overall, the best results, in terms of TBA value and sensory attributes, were obtained for the tteokgalbi containing TS and GS.
\end{abstract}

Keywords: solar salt, tteokgalbi, thiobarbituric acid value, quality

\section{Introduction}

Modern society has brought many changes to the structure and style of dietary habits along with a qualitative improvement of life in Korea, as the technology and information industries have developed. Particularly, westernization of the Korean diet has resulted in a decrease in grain consumption and an increase in meat consumption (Kim et al., 2007). Furthermore, development of the food service industry has facilitated an annual increase in minced beef or pork consumption through hamburger patties, sausage, meatballs, and tteokgalbi (Hansley and Hand, 1995). Tteokgalbi is a type of Korean native local food from galbi, or short ribs which is a good representative of Korean food flavor. Tteok means sticky rice cakes and galbi is a marinated Korean meat dish. Tteokgalbi is grilled short rib meat patties and hand-chopped beef short ribs mixed with vegetables, aromatics, sometimes even

*Corresponding author: Jae-Joon Lee, Department of Food and Nutrition, Chosun University, Gwangju 501-759, Korea. Tel: +82-62-230-7725, Fax: +82-62-225-7726, E-mail: leejj80@ chosun.ac.kr pork into a rectangular appearance, then grilled over a hot charcoal fire. The reason pork and beef are mixed is that beef alone is too dry, so pork is added to make it more fatty. It is loved by people of all ages since its texture is soft and tasty, and available all year round (Choi et al., 2011). Among seasonings used in tteokgalbi, salt improves the taste and flavor of the meat, and melds the proteins in the meat into a gelatinous form to enhance binding quality, chewiness and texture of the meat. It also prevents spoiling of the meat by inhibiting bacterial propagation (Na and Ha, 2009). Therefore, taste, flavor and quality of tteokgalbi may differ according to the kind and composition of the salt used in producing it.

Salt, also commonly referred to as table salt, is a crystalline substance composed primarily of sodium chloride that has been widely used as a food seasoning for thousands of years (Na and Ha, 2009). Salt is one of the major sources of sodium; human blood and cells contain $\sim 0.9 \%$ salt, which is involved in many homeostatic mechanisms. Salt helps maintain the electrochemical potential difference across cell membranes, is involved in material transport, helps control body fluid osmotic pressure, helps maintain acid-base equilibrium, and is involved in the 
transmission of information in our nerves and stimuli in muscles. It also aids in heart function, the digestion and absorption of many nutrients, and in the secretion of the hydrochloric acid component of gastric acid (Chang et al., 2010; Kang, 2006).

As of now, there are three types of salt used in food processing such as solar salt, purified salt, and processed salt (Lee et al., 2007). Purified salt is made from sea water by electrodialysis using ion-exchange membranes and then evaporated in an evaporator tube ( $\mathrm{Na}$ and $\mathrm{Ha}$, 2009). Solar salt is also made from sea water but relies on natural sun- and wind-mediated evaporation of salt brine held in open ponds (Hwang, 1988). Solar salt is classified into Topan solar salt (gray salt) and Jangpan solar salt (white salt) depending on the manufacturing method. Topan solar salt is harvested from the bottom of salt pans covered with soil from tidal fields or yellow soil. Jangpan solar salt is also harvested from the bottom of salt pans, but which have been covered instead with PVC or tiles (Joo et al., 2009). Purified salt contains 99.8\% sodium chloride, while solar salt contains diverse minerals such as calcium, potassium, magnesium, and sulfur, in addition to $92.4-94.4 \%$ sodium chloride (Ha and Park, 1998). Salt produced on the west coast of Korea and the Guérande salt produced in France are solar salts harvested from tidal mudflats. While Korean solar salt contains lower levels of sodium chloride than the world-famous French Guérande salt, it contains more minerals such as potassium and magnesium (Jin et al., 2011). The use of Korean solar salt has been limited as it has been classified as a mineral pursuant under the 1962 Salt Management Act. However, in March 2008 it was reclassified as food by the revised Salt Management Act, allowing the use of solar salt by the food industry (Jeon, 2009). Moreover, similarities in the manufacturing processes of Korean TS and GS have become known to the public, thus drawing attention to Korean TS in both domestic and international salt markets and triggering many studies on Korean solar salt (Jin et al., 2011). However, these studies have focused mostly on mineral content of Korean solar salt (Ha and Park, 1998; Jin et al., 2011), characteristics of salt-fermented food (Cho and Kim, 2010; Lee et al., 2011), and the safety of salt (Kim et al., 2012; $\mathrm{Na}$ and Ha, 2009).

Therefore, the purpose of this study was to compare the quality and characteristics of tteokgalbi, a local dish in South Jeolla Province, seasoned with different types of salt during its storage period in order to promote the use of Korean solar salt and develop recipes that use the salt.

\section{Materials and Methods}

\section{Preparation of tteokgalbi}

Tteokgalbi was produced using a traditional method (Lee et al. 2008, 2013). Boneless beef rib muscle and pork meat from shoulder were obtained fresh from a local meat market. The beef and pork meat were prepared by first removing the connective tissue and excess fat and ground using a meat processor (M-12S, Hankook Fujee Industries Co., Korea) and a grinding plate with $8 \mathrm{~mm}$ diameter holes. The ground beef and pork meat mixed with $3.0 \%$ sugar, $2.8 \%$ scallion, $2.0 \%$ chopped garlic, $0.2 \%$ ground black pepper, $3.0 \%$ sesame oil, $0.5 \%$ ginger juice, $1.2 \%$ chopped onion, $0.5 \%$ rice wine, $1.0 \%$ honey, $0.3 \%$ sesame, $2.0 \%$ starch syrup, $1.0 \%$ flour and $1.5 \%$ purified salt was used as the control (C), and the experimental samples contained one of the solar salts: $1.5 \% \mathrm{FS}$, $1.5 \% \mathrm{TS}$, or $1.5 \% \mathrm{GS}$ (Table 1 ). The meat and ingredients were mixed for $15 \mathrm{~min}$ at $4^{\circ} \mathrm{C}$ by hand. After mixing, the mixtures were stored in a cold room for $1 \mathrm{~d}$. Each mixture was molded to a diameter of $10.0 \mathrm{~cm}$, thickness of $1.2 \mathrm{~cm}$ and a weight of $100 \mathrm{~g}$ using a patty molding machine, and this experiment was performed by opening the package of each experimental group on days $0,5,10$ and 15 while keeping for $15 \mathrm{~d}$ at $5^{\circ} \mathrm{C}$ after vacuum packing in nylon/ polyethylene film.

Table 1. Formula of tteokgalbi prepared with various kinds of salts

\begin{tabular}{ccccc}
\hline \hline Ingredients & $\mathrm{C}^{1)}$ & FS & TS & GS \\
\hline Beef & 70.00 & 70.00 & 70.0 & 70.0 \\
Pork & 10.00 & 10.0 & 10.0 & 10.0 \\
Sugar & 3.00 & 3.00 & 3.00 & 3.00 \\
Scallion & 2.80 & 2.80 & 2.80 & 2.80 \\
Chopped garlic & 2.00 & 2.00 & 2.00 & 2.00 \\
Ground black pepper & 0.20 & 0.20 & 0.20 & 0.20 \\
Sesame oil & 3.0 & 3.0 & 3.0 & 3.0 \\
Ginger & 0.50 & 0.50 & 0.50 & 0.50 \\
Onion & 1.20 & 1.20 & 1.20 & 1.20 \\
Rice wine & 0.50 & 0.50 & 0.50 & 0.50 \\
Honey & 1.00 & 1.00 & 1.00 & 1.00 \\
Sesame & 0.30 & 0.30 & 0.30 & 0.30 \\
Starch syrup & 2.00 & 2.00 & 2.00 & 2.00 \\
Flour & 1.00 & 1.00 & 1.00 & 1.00 \\
Purified salt & 1.50 & 0.00 & 0.00 & 0.00 \\
Five-year-old solar salt & 0.00 & 1.50 & 0.00 & 0.00 \\
Topan solar salt & 0.00 & 0.00 & 1.50 & 0.00 \\
Guérande solar salt & 0.00 & 0.00 & 0.00 & 1.50 \\
\hline
\end{tabular}

${ }^{1)} \mathrm{C}$ (Control: Purified salt 1.5\%), FS (Five-year-old solar salt 1.5\%), TS (Topan solar salt 1.5\%), GS (Guérande solar salt 1.5\%). 


\section{Proximate composition}

The analysis of the proximate composition of samples was conducted in accordance with the method described by the Association of Official Analytical Chemists (AOAC, 1990). Moisture was analyzed using a drying method by heating under atmospheric pressure at $105^{\circ} \mathrm{C}$, crude protein was analyzed by the micro-Kjeldahl method, whereas the crude lipid was analyzed by the Soxhlet extraction method, crude ash was analyzed by the ashing method, and calories were analyzed using a calorimeter (PARR 1351 Bomb Calorimeter, USA).

\section{Measurement of water holding capacity (WHC)}

The measurement of WHC was performed in accordance with the method of Laakkonen et al. (1970). Briefly, $0.5 \pm 0.05 \mathrm{~g}$ of sample was heated at $80^{\circ} \mathrm{C}$ for $20 \mathrm{~min}$ in a water bath (HB-205SW, Hanbaek Scientific Co., Incheon, Korea), allowed to cool to room temperature for $10 \mathrm{~min}$, centrifuged at $6,710 \mathrm{~g}$ at $4^{\circ} \mathrm{C}$ for $10 \mathrm{~min}$ and measured the volume of meat juices in the lower part of the tube, after which is calculated using the equation.

WHO $(\%)=$ extracted meat juice $(\mathrm{mL}) \times 0.951 /$ total moisture in the sample $(\mathrm{g}) \times 100$

0.951: pure water amount for meat moisture which is separated under $70^{\circ} \mathrm{C}$

\section{Measurement of cooking loss}

For cooking loss, the cooking pan was preheated on an open flame for $30 \mathrm{~s}$, and then each tteokgalbi sample was placed on the pan and heated until the center temperature reached at $72^{\circ} \mathrm{C}$ and then cooked for another $15 \mathrm{~min}$. The samples were then transferred to a wire net and allowed to cool for $30 \mathrm{~min}$ and their weights were measured. Cooking loss was calculated as the percentage change in weight before and after cooking.

\section{Texture profile analysis}

The texture profile analysis of the cooked tteokgalbi was measured by the Rheometer (Compac-100, Sun Scientific Co., Japan) and analyzed using Rheology Data System version 2.01 . Table speed was $110 \mathrm{~mm} / \mathrm{min}$, graph interval was $20 \mathrm{~m} / \mathrm{sec}$, and load cell (max) was $10 \mathrm{~kg}$. Hardness (g), cohesiveness, springiness, and chewiness (g) were determined by Bourne (1978).

\section{Sensory evaluation}

Sensory evaluation was conducted after explaining in advance the evaluation content to the evaluation group, which consisted of ten food-related-major students and graduate students who were already knowledgeable about the sensory test. The color, sweetness, saltiness, springiness, flavor, juiciness, and overall acceptability were evaluated on a 5 point scale, where 'extremely good' $=5$ points, 'moderately like' $=3$ points, and 'extremely unlike' = 1 point with respect to each evaluation item. The sample was heated and cooked as described above and then tested by placing it on a white dish after cutting into $2 \mathrm{~cm} \times 2$ $\mathrm{cm} \times 1.5 \mathrm{~cm}$ pieces; drinking water was provided between each sample.

\section{Determination of $\mathrm{pH}$}

The $\mathrm{pH}$ values of tteokgalbi were measured according to the method of Khalil (2000). Ten $g$ of sample was taken and then homogenized for $30 \mathrm{~s}$ by using a Stomacher 400 Lab blender (Seward Ltd., England) in $100 \mathrm{~mL}$ distilled water, and then the $\mathrm{pH}$ of sample was measured with a pH-meter (WTW pH 720, Germany).

\section{2-Thiobarbituric acid value}

Thiobarbituric acid (TBA) value was measured using a modified version of the extraction method by Witte et al. (1970). To $10 \mathrm{~g}$ of each sample was added $15 \mathrm{~mL}$ cold $10 \%$ perchloric acid and $25 \mathrm{~mL}$ triple-distilled water. Samples were homogenized at $10,000 \mathrm{rpm}$ for $10 \mathrm{~s}$ in an AM-Series homogenizer, and the homogenate was followed by filtration through qualitative Whatman filter paper (No. 2, GE Heathcare, UK). Five mL of $0.02 \mathrm{M}$ TBA was added to $5 \mathrm{~mL}$ of sample filtrate and its absorbance was measured at $529 \mathrm{~nm}$ using a DU-650 spectrophotometer (Beckman, USA) after allowing it to stand for $16 \mathrm{~h}$ in a cool and dark place. 1,1,3,3,-Tetraethoxypropane (Sigma-Aldrich, USA) was used as standard for TBA assay. The triple-distilled water served as the blank. TBA values were expressed as mg malonaldehyde (MA) per $1 \mathrm{~kg}$ sample based on a TBA standard curve.

\section{Volatile basic nitrogen (VBN) value}

The content of volatile basic nitrogen (VBN) was measured by microdiffusion analysis (Short, 1954) using a Conway unit. Distilled water $(90 \mathrm{~mL})$ was added to $10 \mathrm{~g}$ of each sample followed by homogenization at 10,000 rpm for $30 \mathrm{~s}$ in an AM-Series homogenizer and filtration using qualitative filter paper No. 2. The filtrate $(1 \mathrm{~mL})$ was placed in the outer chamber of the Conway unit, and $1 \mathrm{~mL} 0.01 \mathrm{~N}$ boric acid and 3 drops of indicator dye $(0.066 \%$ methyl red $+0.066 \%$ bromocresol green $)$ were 
added to the inner chamber. Glycerine was applied to the contact surface of the lid, and the lid was closed and 1 $\mathrm{mL} 50 \% \mathrm{~K}_{2} \mathrm{CO}_{3}$ was injected into the outer chamber. After sealing the chamber and horizontally stirring, the unit was incubated at $37^{\circ} \mathrm{C}$ for $120 \mathrm{~min}$ followed by titrating the boric acid in the inner chamber with $0.02 \mathrm{~N}$ $\mathrm{H}_{2} \mathrm{SO}_{4}$. The value of $\mathrm{VBN}$ was expressed by converting to $\mathrm{mg}$ per $100 \mathrm{~g}$ sample $(\mathrm{mg} \%)$.

\section{$\operatorname{VBN}(\mathrm{mg} \%)=$}

$\{(a-b) \times F \times 28.014 \times 100\} /$ sample weight $(g)$

a: Amount of injected sulfuric acid (mL)

$\mathrm{b}$ : Amount of sulfuric acid injected in blank $(\mathrm{mL})$

F: Standardized index of $0.02 \mathrm{~N} \mathrm{H}_{2} \mathrm{SO}_{4}$

28.014: Amount required to consume $1 \mathrm{~mL} 0.02 \mathrm{~N}$ $\mathrm{H}_{2} \mathrm{SO}_{4}$

\section{Microbiological analysis}

Ten-gram samples were taken aseptically from each treatment, transferred to sterile plastic pouches and homogenized with $90 \mathrm{~mL} 0.1 \%$ peptone solution in a Stomacher 400 Lab Blender (Seward Ltd., England) for $1.5 \mathrm{~min}$. Serial 10 -fold dilutions in liquid culture broth were prepared from each sample and then inoculated on plate count agar (PCA) medium and incubated for $48 \mathrm{~h}$ at $37^{\circ} \mathrm{C}$ (Harrigan and MaCane, 1976). The results were expressed as log colony forming units $(\mathrm{CFU}) / \mathrm{g}$.

\section{Instrumental color evaluation}

The meat color was measured by a spectrocolorimeter (Model JX-777, Color Techno System Co., Japan) that was standardized to the white plate (L, 94.04; a, 0.13; b, -0.51). A white fluorescent lamp (D65) was used as the light source, and the meat color was indicated by the lightness $(L)$, redness $(a)$, and yellowness $(b)$ values of Hunter lab color coordinates.

\section{Statistical analysis}

Three replications of this study were performed and measured of all parameters were made in duplicate. Statistical analysis was performed by computing analysis of variance using the SAS program (2002) and significance was verified at the level of 5\% using Duncan's multiple range test.

\section{Results and Discussion}

\section{Proximate composition and calorie content of tteok- galbi added with various kinds of salts}

The proximate composition and calorie content of tteokgalbi prepared with various kinds of salts are shown in Table 2. Moisture and crude ash contents of tteokgalbi did not show significant differences regardless of the addition of various kinds of salts. The crude lipid and crude protein contents were also not significantly different between control and all other treatments. According to a study by Jang et al. (2011), the moisture contents of purified salt and solar salt are $0.01 \%$ and $10.76-12.51 \%$, respectively. A study by Kim et al. (2005) reported that the quantities of microelements in these two salts are $1.3 \%$ and $3.3 \%$, respectively. Na et al. (2012) found that the iron and zinc contents of gray salt (Topan salt) were higher than those of white salt (Jangpan salt) while the calcium, potassium, and magnesium contents were lower than those of white salt. Jin et al. (2011) reported that the sodium chloride contents of white salt, gray salt and French Guérande salt (gray salt) were $85.1,89.3$, and $91.3 \%$, respectively. The sodium content of the white salt was found to be slightly lower than that of Guérande salt while magnesium and potassium contents of the white salt were found to be higher than those of Guérande salt. Little difference in this study was detected in the moisture and crude ash contents of tteokgalbi, probably because only slight amounts of salt were added. Total calories content of tteokgalbi ranged between $\sim 2,248.00-2,314.00 \mathrm{kcal} / \mathrm{g}$ with no statis-

Table 2. Proximate compositions of tteokgalbi prepared with various kinds of salts

\begin{tabular}{cccc}
\hline \hline Items & \multicolumn{2}{c}{ Treatments $^{1)}$} & TS \\
\cline { 2 - 4 } & $\mathrm{C}$ & $65.32 \pm 0.41$ & $66.06 \pm 0.43$ \\
Moisture (\%) & $66.10 \pm 0.32^{2) \mathrm{NS} 3)}$ & $8.02 \pm 0.14$ & $7.62 \pm 0.29$ \\
Crude lipid (\%) & $7.58 \pm 0.46^{\mathrm{NS}}$ & $2.74 \pm 0.08$ & $2.80 \pm 0.08$ \\
Crude ash (\%) & $2.80 \pm 0.13^{\mathrm{NS}}$ & $23.91 \pm 0.12$ & $23.53 \pm 0.38$ \\
Crude protein (\%) & $23.52 \pm 0.52^{\mathrm{NS}}$ & $2248.00 \pm 58.89$ & $2.65 \pm 0.05$ \\
Calorie (kcal/g) & $2305.00 \pm 48.50^{\mathrm{NS}}$ & $24.13 \pm 0.13$ & $2313.00 \pm 60.04$ \\
\hline
\end{tabular}

1) Treatment: See the Table 1 legend.

${ }^{2)}$ All values are expressed as mean \pm SEM of triplicate determinations.

${ }^{3)} \mathrm{NS}$ : Not significant. 
Table 3. Water holding capacity (WHC) and cooking loss of tteokgalbi prepared with various kinds of salts

\begin{tabular}{ccccc}
\hline \hline \multirow{2}{*}{ Items } & \multicolumn{3}{c}{ Treatments $^{\text {(1) }}$} \\
\cline { 2 - 5 } & $\mathrm{C}$ & $\mathrm{FS}$ & $\mathrm{TS}$ & GS \\
\hline WHC (\%) & $71.69 \pm 0.78^{2) \mathrm{NS} 3)}$ & $71.60 \pm 1.00$ & $72.46 \pm 3.88$ & $72.44 \pm 0.79$ \\
Cooking loss (\%) & $19.94 \pm 0.10^{\mathrm{NS}}$ & $19.60 \pm 0.39$ & $19.73 \pm 0.71$ & $19.69 \pm 1.56$ \\
\hline
\end{tabular}

${ }^{1)}$ Treatment: See the Table 1 legend.

${ }^{2)}$ All values are expressed as mean $\pm \mathrm{SEM}$ of triplicate determinations.

${ }^{3)} \mathrm{NS}$ : not significant.

Table 4. Textural properties of tteokgalbi prepared with various kinds of salts

\begin{tabular}{ccccc}
\hline \hline \multirow{2}{*}{ Items } & \multicolumn{4}{c}{ Treatments $^{\text {I) }}$} \\
\cline { 2 - 5 } & $\mathrm{C}$ & FS & TS & GS \\
\hline Hardness (g) & $1664.00 \pm 92.23^{2) 63)}$ & $2054.00 \pm 97.86^{\text {ab }}$ & $1958.00 \pm 179.68^{\text {ab }}$ & $2502.00 \pm 233.46^{\text {a }}$ \\
Cohesiveness (\%) & $33.69 \pm 1.47^{\mathrm{NS} 4)}$ & $35.14 \pm 1.41$ & $34.63 \pm 2.58$ & $33.18 \pm 4.04$ \\
Springiness (\%) & $48.13 \pm 0.94^{\mathrm{NS}}$ & $53.84 \pm 3.98$ & $47.35 \pm 1.54$ & $53.91 \pm 2.87$ \\
Chewiness (g) & $269.50 \pm 18.82^{\mathrm{NS}}$ & $397.21 \pm 49.49$ & $332.53 \pm 55.89$ & $461.57 \pm 91.86$ \\
\hline
\end{tabular}

${ }^{1)}$ Treatment: See the Table 1 legend.

${ }^{2)}$ All values are expressed as mean \pm SEM of triplicate determinations.

${ }^{3)}$ Means in the same row not sharing a common letter are significantly different $(p<0.05)$ by Duncan's multiple range test.

${ }^{4)}$ NS: Not significant.

tically significant differences. These results suggest that the addition of these solar salts does not significantly affect the proximate composition and calorie content of tteokgalbi compared to control.

\section{Water holding capacity (WHC) and cooking loss of tteokgalbi added with various kinds of salts}

The WHC and cooking loss results of tteokgalbi prepared with various kinds of salts are shown in Table 3. The WHC value and cooking loss were not significantly different among the tteokgalbi preparations. WHC is defined as the ability of food to hold all or part of its own water without losing water to the spaces between original fibers (Huff-Lonergan and Lonergan, 2005). When meat is heated, fat and moisture tend to be discharged from the meat, decreasing the weight and size of the meat. Palatability tends to decrease if there is too much loss due to heating (Berry and Leddy, 1989). Cooking loss is known to be affected by many factors such as size and shape of the minced meat, type and content of fat, salt content, amount of additives, composition of the meat, etc. (Ruusunen et al., 2005; Tarrant et al., 1985). Ruusunen et al. (2005) reported that increase sodium content could reduce cooking loss. These results suggest the addition of the solar salts does not significantly affect the WHC or cooking loss of tteokgalbi compared to control salt.

Texture properties of tteokgalbi added with various kinds of salts

Results from the texture properties analysis of tteok- galbi added with various kinds of salts are shown in Table 4. In terms of hardness, the lowest value was found in the control group, while the highest value was found in the GS. However, the cohesiveness, springiness and chewiness of tteokgalbi were not significantly different among the groups. In general, sodium chloride increased the hardness. The hardness and chewiness are affected by various factors such as the moisture and fat contents of meat products, and the kinds of additives (Song et al., 2000). When salt is added to meat, myofibrillar proteins in muscle become solubilized, which enhances binding strength and creates a unique chewiness and texture ( $\mathrm{Na}$ and $\mathrm{Ha}, 2009$ ). In this study, there was slightly increased hardness score of tteokgalbi added with GS compared to the other samples. But moisture and fat contents were not significantly different among the tteokgalbi added with various kinds of salts. Thus, further research will be required to evaluate the differences in hardness depending on the different types of salt.

\section{Sensory evaluation of tteokgalbi added with vari- ous kinds of salts}

The sensory properties of tteokgalbi added with the various kinds of salts are shown in Table 5. The color, sweetness, and saltiness were not significantly different among the groups. The juiciness of tteokgalbi added with the solar salts (FS, TS and GS) received overall higher scores than the control group, but there were no statistically significant differences. Springiness of tteokgalbi added with TS was judged significantly better than the control (C). For 
Table 5. Sensory evaluation of tteokgalbi prepared with various kinds of salts

\begin{tabular}{ccccc}
\hline \hline Sensory & \multicolumn{3}{c}{ Treatments $^{\text {I) }}$} \\
\cline { 2 - 5 } Characteristics $^{2)}$ & C & FS & TS & GS \\
\hline Color & $3.94 \pm 0.23^{3)^{N S 4}}$ & $3.43 \pm 0.20$ & $3.88 \pm 0.24$ & $3.58 \pm 0.28$ \\
Sweetness & $2.95 \pm 0.21^{\mathrm{NS}}$ & $2.93 \pm 0.17$ & $3.24 \pm 0.27$ & $3.16 \pm 0.24$ \\
Saltness & $3.81 \pm 0.36^{\mathrm{NS}}$ & $3.57 \pm 0.32$ & $3.19 \pm 0.37$ & $3.17 \pm 0.33$ \\
Juiciness & $3.61 \pm 0.26^{\mathrm{NS}}$ & $4.18 \pm 0.28$ & $4.41 \pm 0.36$ & $4.19 \pm 0.38$ \\
Springiness & $3.50 \pm 0.19^{\mathrm{b} 5)}$ & $4.09 \pm 0.18^{\mathrm{ab}}$ & $4.61 \pm 0.25^{\mathrm{a}}$ & $4.24 \pm 0.40^{\mathrm{ab}}$ \\
Flavor & $3.57 \pm 0.20^{\mathrm{b}}$ & $4.03 \pm 0.24^{\mathrm{b}}$ & $4.77 \pm 0.23^{\mathrm{a}}$ & $4.83 \pm 0.16^{\mathrm{a}}$ \\
Total acceptability & $3.11 \pm 0.20^{\mathrm{b}}$ & $4.06 \pm 0.24^{\mathrm{a}}$ & $4.44 \pm 0.26^{\mathrm{a}}$ & $4.93 \pm 0.28^{\mathrm{a}}$ \\
\hline
\end{tabular}

${ }^{1)}$ Treatment: See the Table 1 legend.

${ }^{2)} 1$ : dislike extremely, 3: neither like nor dislike, 5: like extremely.

${ }^{3)}$ All values are expressed as mean \pm SEM of triplicate determinations.

${ }^{4)}$ NS: Not significant.

${ }^{5)}$ Means in the same row not sharing a common letter are significantly different $(p<0.05)$ as determined by Duncan's multiple range test.

Table 6. pH changes of total aerobic counts for raw tteokgalbi prepared with various kinds of salts during $15 \mathrm{~d} \mathrm{of} \mathrm{storage} \mathrm{at} 5^{\circ} \mathrm{C}$

\begin{tabular}{cccccc}
\hline \hline & storage time $(\mathrm{d})$ & \multicolumn{3}{c}{ Treatments $^{\mathrm{I}}$} \\
\cline { 3 - 6 } & & $\mathrm{C}$ & $\mathrm{FS}$ & $\mathrm{TS}$ & $\mathrm{GS}$ \\
\hline \multirow{3}{*}{$\mathrm{pH}$} & 0 & $5.91 \pm 0.01^{2 \mathrm{b3}) \mathrm{A} 4)}$ & $5.98 \pm 0.01^{\mathrm{aA}}$ & $5.93 \pm 0.01^{\mathrm{bA}}$ & $5.94 \pm 0.01^{\mathrm{bA}}$ \\
& 5 & $5.21 \pm 0.02^{\mathrm{cB}}$ & $5.31 \pm 0.03^{\mathrm{bB}}$ & $5.47 \pm 0.03^{\mathrm{aB}}$ & $5.43 \pm 0.01^{\mathrm{aB}}$ \\
& 10 & $4.66 \pm 0.01^{\mathrm{aC}}$ & $4.60 \pm 0.01^{\mathrm{bC}}$ & $4.61 \pm 0.01^{\mathrm{bC}}$ & $4.64 \pm 0.01^{\mathrm{abC}}$ \\
& 15 & $4.49 \pm 0.01^{\mathrm{bD}}$ & $4.56 \pm 0.01^{\mathrm{aC}}$ & $4.55 \pm 0.01^{\mathrm{aD}}$ & $4.55 \pm 0.01^{\mathrm{aD}}$ \\
\hline
\end{tabular}

${ }^{1)}$ Treatment : See the Table 1 legend.

${ }^{2)}$ All values are expressed as mean \pm SEM of triplicate determinations.

${ }^{3) a-d}$ Means with different superscripts within a row differ significantly $(p<0.05)$.

${ }^{4) A-D}$ Means with different superscripts within a column differ significantly $(p<0.05)$.

flavor and overall acceptability, teokgalbi added with TS and GS were considered significantly better than the control (C). When meat products are heated, their palatability depends on ATP-related chemicals, sugars, organic acids, fatty acids, content of free amino acids and peptides and the type of muscle (Watanabe and Sato, 1974). The types and amounts of supplementary materials added to the meat product also greatly affect its palatability. As opposed to purified salt, which contains relatively high levels of sodium chloride, solar salt with its greater variety of minerals tends to enhance the palatability of meat products (Kim and Kim 2013). Therefore, tteokgalbi added with TS that contains many minerals and that added with GS produced positive results in terms of flavor and overall palatability.

\section{Changes in pH of raw tteokgalbi added with vari- ous kinds of salts}

Table 6 shows the $\mathrm{pH}$ changes in raw tteokgalbi added by refrigeration at $5^{\circ} \mathrm{C}$ with various kinds of salts over 15 days. The $\mathrm{pHs}$ immediately after preparing the raw tteokgalbi with the four kinds of salts (C, FS, TS and GS) were 5.91, 5.98, 5.93 and 5.94, respectively, while after storage $15 \mathrm{~d}$ the $\mathrm{pH}$ values dropped to 4.49, 4.56, 4.55 and 4.55, respectively. Tteokgalbi added with TS and GS showed the highest $\mathrm{pH}$ values in comparison with the control group (C) after storage $5 \mathrm{~d}$. Tteokgalbi added with FS and TS showed the lowest $\mathrm{pH}$ values in comparison with the control group after storage $10 \mathrm{~d}$. Tteokgalbi added with solar salts (FS, TS and GS) showed significantly higher $\mathrm{pH}$ values in comparison with the control group (C) after storage $15 \mathrm{~d}$. The different kinds of salt added to raw tteokgalbi seemed to have produced no changes in the $\mathrm{pH}$ value of meat products.

\section{Changes in TBA value of raw tteokgalbi added with various kinds of salts}

The TBA values in raw tteokgalbi added with various kinds of salts during refrigerated storage over $15 \mathrm{~d}$ are shown in Table 7. Initial TBA values for the control tteokgalbi added with purified salt and tteokgalbi added with various solar salts were significantly different. Moreover, the TBA value of tteokgalbi added with GS was significantly lower than the other treatment groups. However, TBA values in the meat products increased significantly over time; from the $10 \mathrm{~d}$ of the storage period, TBA values in tteokgalbi added with TS and GS were significantly lower than that of the control group (C). TBA is widely used as indicator of lipid oxidation in meat stud- 
Table 7. Changes of TBA values for raw tteokgalbi prepared with various kinds of salts during $15 \mathrm{~d}$ of storage at $5^{\circ} \mathrm{C}$

\begin{tabular}{cccccc}
\hline \hline & \multirow{2}{*}{ storage time $(\mathrm{d})$} & \multicolumn{3}{c}{ Treatments } \\
\cline { 2 - 6 } & & $\mathrm{C}$ & $\mathrm{FS}$ & $\mathrm{TS}$ & $\mathrm{GS}$ \\
\hline & 0 & $0.29 \pm 0.01^{2 \mathrm{a}) \mathrm{D}) \mathrm{D} 4)}$ & $0.26 \pm 0.01^{\mathrm{bD}}$ & $0.24 \pm 0.01^{\mathrm{cD}}$ & $0.22 \pm 0.01^{\mathrm{dD}}$ \\
TBA & 5 & $0.40 \pm 0.01^{\mathrm{aC}}$ & $0.37 \pm 0.01^{\mathrm{bC}}$ & $0.32 \pm 0.01^{\mathrm{cC}}$ & $0.28 \pm 0.01^{\mathrm{dC}}$ \\
$(\mathrm{mg} \mathrm{MA} / \mathrm{kg})$ & 10 & $0.50 \pm 0.01^{\mathrm{aB}}$ & $0.42 \pm 0.01^{\mathrm{bB}}$ & $0.37 \pm 0.01^{\mathrm{cB}}$ & $0.36 \pm 0.01^{\mathrm{cB}}$ \\
& 15 & $0.65 \pm 0.02^{\mathrm{aA}}$ & $0.50 \pm 0.01^{\mathrm{bA}}$ & $0.46 \pm 0.01^{\mathrm{cA}}$ & $0.45 \pm 0.01^{\mathrm{cA}}$ \\
\hline
\end{tabular}

${ }^{1)}$ Treatment : See the Table 1 legend.

${ }^{2)}$ All values are expressed as mean \pm SEM of triplicate determinations.

${ }^{3) a-d}$ Means with different superscripts within a row differ significantly $(p<0.05)$.

${ }^{4) A-D}$ Means with different superscripts within a column differ significantly $(p<0.05)$.

Table 8. Changes of VBN values for raw tteokgalbi prepared with various kinds of salts during $15 \mathrm{~d}$ of storage at $5^{\circ} \mathrm{C}$

\begin{tabular}{cccccc}
\hline \hline & \multicolumn{4}{c}{ Treatments $^{\mathrm{I}}$} \\
\cline { 3 - 6 } & \multirow{2}{*}{ storage time $(\mathrm{d})$} & $\mathrm{C}$ & $\mathrm{FS}$ & $\mathrm{TS}$ & $\mathrm{GS}$ \\
\cline { 2 - 6 } & & $7.78 \pm 0.46^{2 \mathrm{a} 3) \mathrm{C} 4)}$ & $6.95 \pm 0.24^{\mathrm{abD}}$ & $6.59 \pm 0.16^{\mathrm{bD}}$ & $5.95 \pm 0.09^{\mathrm{bD}}$ \\
$\mathrm{VBN}$ & 5 & $10.57 \pm 0.32^{\mathrm{NS}) \mathrm{B}}$ & $9.75 \pm 0.01^{\mathrm{C}}$ & $9.20 \pm 0.16^{\mathrm{C}}$ & $9.29 \pm 0.56^{\mathrm{C}}$ \\
$(\mathrm{mg} \%)$ & 10 & $11.67 \pm 0.16^{\mathrm{aB}}$ & $11.58 \pm 0.09^{\mathrm{aB}}$ & $10.39 \pm 0.16^{\mathrm{bB}}$ & $10.75 \pm 0.24^{\mathrm{bB}}$ \\
& 15 & $15.88 \pm 0.33^{\mathrm{NSA}}$ & $15.98 \pm 0.18^{\mathrm{A}}$ & $15.79 \pm 0.27^{\mathrm{A}}$ & $15.88 \pm 0.18^{\mathrm{A}}$ \\
\hline
\end{tabular}

${ }^{1)}$ Treatment: See the Table 1 legend.

${ }^{2)}$ All values are expressed as mean \pm SEM of triplicate determinations.

${ }^{3) a-d}$ Means with different superscripts within a row differ significantly $(p<0.05)$.

4)A-D Means with different superscripts within a column differ significantly $(p<0.05)$.

${ }^{5)} \mathrm{NS}$ : Not significant.

ies. Sheard et al. (2000) indicate MA concentrations higher than $0.5 \mathrm{mg} / \mathrm{kg}$ as threshold values for rancidity perception by consumers. In the present study, the purified salt samples would be perceived as rancid after $10 \mathrm{~d}$ of storage whereas in the solar salts treatments MA concentrations did not exceed $0.5 \mathrm{mg} / \mathrm{kg}$ at the end of the storage period. Buckely et al. (1989) reported that sodium chloride affected lipid oxidation due to the release of iron ions from heme pigments. According to this result, it seems that purified salt (C) promoted lipid oxidation faster than Topan solar salt (TS) and Guérande solar salt (GS). TS and GS were still prooxidative, but it was weaker than purified salt. Different composition and amounts of minerals in salt affect the production of peroxides; it has been reported that solar salt is more effective than purified salt in inhibiting production of peroxides (Ha and Park, 1999). Therefore, our results suggest that the composition and amounts of minerals in Korean TS and French GS inhibited the lipid oxidation of the tteokgalbis seasoned with these two salts.

\section{Changes in VBN values of raw tteokgalbi added with various kinds of salts}

The VBN contents in raw tteokgalbi added refrigerated with various kinds of salts over $15 \mathrm{~d}$ are shown in Table 8 . VBN content is considered an important index of meat product freshness. Proteins are decomposed into low molec- ular weight substances such as albumose, peptone, peptides and amino acids, and then undergo reduction by bacteria to produce VBN (Crespo et al., 1978); thus, an increase in bacteria and enzyme activity lead to an increase in VBN content. Foods with VBN content below $20 \mathrm{mg} \%$ are considered safe to eat (Korean Food \& Drug Administration, 2002). In this study, VBN contents, as well as the microbial counts, increased significantly during storage. At $10 \mathrm{~d}$, the control and FS samples had significantly higher VBN value of 11.7 and $11.6 \mathrm{mg} \%$, compared with those of the samples with TS and GS added (10.4 and 10.8 $\mathrm{mg} \%$, respectively). These results suggest that the shelflife of the tteokgalbi may be improved slightly by TS and GS. However, all of them remained fresh, with VBN content below $20 \mathrm{mg} \%$. Na and $\mathrm{Ha}$ (2009) have reported that salts in food generally prevent decomposition by inhibiting the growth of harmful foodborn microorganisms. Therefore, these data suggest that salt delayed the decomposition of protein in our tteokgalbi preparations by inhibiting the growth of harmful foodborn microorganism.

\section{Changes in total aerobic bacteria of raw tteokgalbi added with various kinds of salts}

The total bacteria counts in raw tteokgalbi added refrigerated with various kinds of salt over $15 \mathrm{~d}$ are shown in Table 9. On the day of production, total plate counts in tteokgalbi ranged between 3.63-4.13 Log CFU/g and tteok- 
galbi with TS had the smallest count. Over time, however, these counts increased significantly. On the 5 and $10 \mathrm{~d}$ of storage, the counts in tteokgalbi with TS and GS were significantly lower than that of the control (C). On the $15 \mathrm{~d}$, the total plate counts in all tteokgalbis ranged between 7.30-7.72 Log CFU/g, and showed no significant differences. Jang et al. (1995) have reported that the growth of putrefactive bacteria at $5^{\circ} \mathrm{C}$ was inhibited in $2 \%$ salt steep liquid, while the preservability of the meat products was lengthened by $40-50 \mathrm{~h}$ in $3-4 \%$ salt steep liquid. In the current study, tteokgalbi was seasoned with $1.5 \%$ of the various salts, but only tteokgalbi seasoned with TS showed inhibition in the growth of microbial counts. These differences probably derived from the different composition of minerals in each salt. However, further investigation is needed as the inhibiting effects of the salts were not robust.

\section{Instrumental color surface of raw tteokgalbi added} with various kinds of salts

Table 10 shows the results for instrumental surface color values of tteokgalbi added with various kinds of salts. $L$ values represent lightness, while $b$ values represent yellow color range. The two values were significantly low in tteokgalbi added with TS immediately following preparation, but differences between the control group (C) and solar salt groups (FS, FS and GS) decreased with time. While lightness of tteokgalbis added with $\mathrm{C}$ and FS decreased with time, lightness of tteokgalbis added with GS remained virtually constant during the storage period except on the day of preparation. However, lightness of tteokgalbis added with TS remained virtually constant during the whole period. The $a$ values, which represent red color range, of tteokgalbi during the entire storage period, was not affected by the addition of salts. These results coincide with the report of Farouk and Swan (1998) that the changes in ionic strength due to the addition of salts did not influence the redness value of meat. On the other hand, Anderson et al. (1990) showed that the addition of $0.1 \%$ sodium chloride to minced meat tended to increase discoloration. It suggests that the red-

Table 9. Changes of total aerobic counts for raw tteokgalbi prepared with various kinds of salts during $15 \mathrm{~d}$ of storage at $5^{\circ} \mathrm{C}$

\begin{tabular}{|c|c|c|c|c|c|}
\hline & \multirow{2}{*}{ storage time (d) } & \multicolumn{4}{|c|}{ Treatments ${ }^{I)}$} \\
\hline & & $\mathrm{C}$ & $\mathrm{FS}$ & $\mathrm{TS}$ & GS \\
\hline \multirow{4}{*}{$\log \mathrm{CFU} / \mathrm{g}$} & 0 & $4.13 \pm 0.01^{2) \mathrm{a} 3)(4)}$ & $3.93 \pm 0.09^{\mathrm{aD}}$ & $3.63 \pm 0.01^{\mathrm{bC}}$ & $3.97 \pm 0.01^{\mathrm{aC}}$ \\
\hline & 5 & $6.39 \pm 0.01^{\mathrm{aB}}$ & $5.95 \pm 0.02^{\mathrm{bC}}$ & $6.04 \pm 0.03^{\mathrm{bB}}$ & $5.95 \pm 0.03^{\mathrm{bB}}$ \\
\hline & 10 & $6.66 \pm 0.02^{\mathrm{aB}}$ & $6.40 \pm 0.12^{\mathrm{abB}}$ & $6.20 \pm 0.08^{\mathrm{bB}}$ & $6.09 \pm 0.05^{\mathrm{bB}}$ \\
\hline & 15 & $7.72 \pm 0.12^{\mathrm{NSA}}$ & $7.60 \pm 0.01^{\mathrm{A}}$ & $7.39 \pm 0.09^{\mathrm{A}}$ & $7.30 \pm 0.30^{\mathrm{A}}$ \\
\hline
\end{tabular}

${ }^{1)}$ Treatment : See the Table 1 legend.

${ }^{2)}$ All values are expressed as mean \pm SEM of triplicate determinations.

${ }^{3) a-d}$ Means with different superscripts within a row differ significantly $(p<0.05)$.

4)A-D Means with different superscripts within a column differ significantly $(p<0.05)$.

Table 10. Color properties ( $L, a$, and $b)$ of raw tteokgalbi prepared with various kinds of salts during $15 \mathrm{~d}$ of storage at $5^{\circ} \mathrm{C}$

\begin{tabular}{|c|c|c|c|c|c|}
\hline & \multirow{2}{*}{ storage time (d) } & \multicolumn{4}{|c|}{ Treatments ${ }^{I)}$} \\
\hline & & $\mathrm{C}$ & FS & $\mathrm{TS}$ & GS \\
\hline \multirow{4}{*}{$\mathrm{L}$} & 0 & $47.79 \pm 1.43^{2 \mathrm{a} 3) \mathrm{A} 4)}$ & $46.30 \pm 1.05^{\mathrm{aA}}$ & $40.58 \pm 0.88^{\mathrm{bNS}}$ & $50.60 \pm 1.33^{\mathrm{aA}}$ \\
\hline & 5 & $43.22 \pm 0.31^{\mathrm{NS} 5) \mathrm{AB}}$ & $43.86 \pm 1.59^{\mathrm{AB}}$ & $41.94 \pm 0.63$ & $41.72 \pm 1.09^{\mathrm{B}}$ \\
\hline & 10 & $43.37 \pm 0.55^{\mathrm{NSAB}}$ & $41.72 \pm 1.05^{\mathrm{AB}}$ & $42.24 \pm 1.07$ & $42.06 \pm 1.92^{\mathrm{B}}$ \\
\hline & 15 & $42.07 \pm 0.74^{\mathrm{NSB}}$ & $40.84 \pm 0.41^{\mathrm{B}}$ & $43.73 \pm 1.14$ & $42.84 \pm 1.56^{\mathrm{B}}$ \\
\hline \multirow{4}{*}{$\mathrm{a}$} & 0 & $12.03 \pm 0.78^{\mathrm{NS}}$ & $10.45 \pm 0.58^{\mathrm{NS}}$ & $12.04 \pm 1.09^{\mathrm{NS}}$ & $10.16 \pm 0.90^{\mathrm{NS}}$ \\
\hline & 5 & $11.31 \pm 0.41^{\mathrm{NS}}$ & $11.87 \pm 0.23$ & $11.08 \pm 0.85$ & $10.43 \pm 0.68$ \\
\hline & 10 & $11.51 \pm 0.23^{\mathrm{NS}}$ & $10.53 \pm 0.06$ & $10.86 \pm 0.29$ & $10.43 \pm 0.34$ \\
\hline & 15 & $10.50 \pm 0.28^{\mathrm{NS}}$ & $11.65 \pm 0.14$ & $9.39 \pm 1.16$ & $10.05 \pm 0.61$ \\
\hline \multirow{4}{*}{$\mathrm{b}$} & 0 & $17.23 \pm 0.25^{\mathrm{a} A}$ & $17.19 \pm 0.21^{\mathrm{aA}}$ & $15.08 \pm 0.60^{\mathrm{bNS}}$ & $18.30 \pm 0.22^{\mathrm{aA}}$ \\
\hline & 5 & $15.00 \pm 0.07^{\mathrm{NSB}}$ & $15.24 \pm 0.87^{\mathrm{A}}$ & $13.88 \pm 0.33$ & $14.70 \pm 0.59^{\mathrm{B}}$ \\
\hline & 10 & $15.46 \pm 0.22^{\mathrm{NSB}}$ & $15.61 \pm 0.80^{\mathrm{A}}$ & $14.42 \pm 0.40$ & $13.94 \pm 1.32^{\mathrm{B}}$ \\
\hline & 15 & $11.75 \pm 0.35^{\mathrm{NSC}}$ & $12.87 \pm 0.43^{\mathrm{B}}$ & $13.93 \pm 1.55$ & $13.76 \pm 0.83^{\mathrm{B}}$ \\
\hline
\end{tabular}

${ }^{1)}$ Treatment: See the Table 1 legend.

${ }^{2)}$ All values are expressed as mean \pm SEM of triplicate determinations.

${ }^{3) a-d}$ Means with different superscripts within a row differ significantly $(p<0.05)$.

4)A-D Means with different superscripts within a column differ significantly $(p<0.05)$.

${ }^{5)}$ NS: Not significant. 
ness value due to treatment did not change with the addition of different salts. Cheng et al. (2007) reported that raw pork patties showed lower yellowness or redness when higher lipid oxidation happened. Lipid oxidation contributes to the deterioration of redness (Faustman et al., 2010). In this study, the addition of purified salt (C) of sample had slightly higher TBA value compared to tteokgalbi added with TS and GS. However, $a$ value of tteokgalbi did not significantly change among the treatments. Badr (2007) reported that the addition of salt slowed down the accumulation of metmyoglobin in raw beef patties.

\section{Conclusion}

The purpose of this study was to compare the quality and characteristics of tteokgalbi added with different types of salt during refrigerated storage. Taken together, our results suggest that the type of salt used in tteokgalbi affects the quality and preservability of the meat products. In particular, lipid oxidation in tteokgalbi added with Topan solar salt and Guérande solar salt was effectively inhibited. Tteokgalbi added with Topan solar salt scored highly in sensory attributes, demonstrating an outstanding quality that is as competitive as that of French guérande solar salt.

\section{Acknowledgements}

This work was supported by a research grant from Hankyong National University in 2013.

\section{References}

1. Anderson, H. J., Berertelsen, G., and Skibsted, L. H. (1990) Colour and colour stability of hot processed frozen minced beef. Result from chemical model experiments tested under storage condition. Meat Sci. 28, 87-97.

2. AOAC (1990) Official methods of analysis. 15th ed. Association of Official Analytical Chemists, Washington, DC, USA. p. 788.

3. Bard, H. M. (2007) Antioxidative activity of carnosine in gamma irradiated ground beef and beef patties. Food Chem. 104, 665-679.

4. Berry, B. W. and Leddy, K. F. (1989) Effects of freezing rate, frozen storage temperature and storage time on tenderness values of beef patties. J. Food Sci. 54, 291-296.

5. Bourne, M. C. (1978) Texture profile analysis. Food Technol. 33, 62-66.

6. Buckely, D. J., Gray, J. I., Asghar, A., Price, J. F., Krackel, R. L., Booren, A. M., Pearson, A. M., and Miller, E. R. (1989) Effects of dietary antioxidants and oxidized oil on membrane lipid stability and pork product quality. J. Food Sci. 54, 11931197.

7. Chang, M. S., Cho, S. D., Bae, D. H., and Kim, G. H. (2010) Safety and quality assessment of Kimchi made using various salts. Korean J. Food Sci. Technol. 42, 160-164.

8. Cheng, J. H., Wang, S. T., and Ockerman, H. W. (2007) Lipid oxidation and color change of salted pork patties. Meat Sci. 75, 71-77.

9. Cho, S. D. and Kim, G. H. (2010) Changes of quality characteristics of salt-fermented shrimp prepared with various salts. Korean J. Food \& Nutr. 23, 291-298.

10. Choi, J. S., Jung, D. S., Kang, T. Y., and Choi, Y. I. (2011) Quality characteristics of tteokgalbi made with non-preferred portion of dairy beef. J. Agr. Sci. Chungbuk Nat'l Univ. 27, 9397.

11. Crespo, F. L., Millan, R., and Moreno, A. S. (1978) Chemical changes during ripening of a Spanish dried sausage. 3. Changes in water-soluble nitrogen compounds. Archivos de Zootecnia. 27, 105-116.

12. Farouk, M. M. and Swan, J. E. (1998) Effect of muscle condition before freezing and simulated chemical changes during frozen storage on the $\mathrm{pH}$ and colour of beef. Meat Sci. 50, 245-256.

13. Faustman, C., Sun, Q., Mancini, R., and Suman, S. P. (2010) Myoglobin and lipid oxidation interactions: Mechanistics bases and control. Meat Sci. 86, 86-94.

14. Ha, J. O. and Park, K. Y. (1998) Comparison of mineral contents and external structure of various salts. J. Korean Soc. Food Sci. Nutr. 27, 413-418.

15. Ha, J. O. and Park, K. Y. (1999) Comparison of autooxidation rate and comutagenic effect of different kinds of salt. $J$. Kor. Assoc. Cancer Preven. 4, 44-51.

16. Hansley, J. L. and Hand, L. W. (1995) Formulation and chopping temperature effects on beef frankfurters. J. Food Sci. 60, 55-57.

17. Harrigan, W. F. and MaCane, M. E. (1976) Laboratory methods in food and dairy microbiology. Academic Press, London, UK. pp. 753-850.

18. Huff-Lonergan, E. and Lonergan, S. M. (2005) Mechanism of water holding capacity of meat: the role of postmortem biochemical and structural changes. Meat Sci. 71, 194-203.

19. Hwang, S. H. (1988) A study on the heavy metal contents of common salts in Korean. Korean J. Environ. Hlth. Soc. 14, 73-86.

20. Jang, J. Y., Kim, I. C., and Jang, H. C. (2011) Effect of solar salt on the fermentation characteristics of kimchi. Korean $J$. Food Preserv. 18, 256-265.

21. Jang, W. Y., Shin, D. H., and Kim, B. Y. (1995) Studies on the physical properties of soybean curd stored in the solution of different salt concentration. J. Korean Soc. Applied Bio. Chem. 38, 135-140.

22. Jeon, H. Y. (2009) New growth engines: Strategy for high value-added food industry. Food Sci. Indus. 42, 3-11.

23. Jin, Y. X., Je, J. H., Lee, Y. H., Kim, J. H., Cho, Y. S., and Kim, S. Y. (2011) Comparison of the mineral contents of sundried salt depending on wet digestion and dissolution. Korean 
J. Food Preserv. 18, 993-997.

24. Joo, M. B., Kang, J. H., Chang, H. S., and Lee, H. D. (2009) Strategy study for high-valued food industrialization of solar salt. Korea Maritime Institute, Seoul, Korea, pp. 25-27.

25. Kang, J. H. (2006) Salt and health. Korea Forum 6. Korea Forum Corporation, Seoul, Korea. pp. 200-203.

26. Khalil, A. H. (2000) Quality characteristics of low-fat beef patties formulated with modified corn starch and water. Food Chem. 68, 61-68.

27. Kim, D. H. (1997) Food chemistry. Tamkudang, Seoul, Korea. pp. 677-696.

28. Kim, H. L., Yoo, Y. J., Lee, I. S., Ko, G. H., and Kim, I. C. (2012) Evaluation of heavy metal contents in mudflat solar salt, salt water, and sea water in the nationwide salt pan. $J$. Korean Soc. Food Sci. Nutr. 41, 1014-1019.

29. Kim, K. M. and Kim I. C. (2013) The physical and chemical properties of salt manufactured by new process with brine produced in Korean salt-farms. J. Korean Soc. Food Sci. Nutr. 42, 1664-1672.

30. Kim, S. J., Kim, H. L., and Ham, K. S. (2005) Characterization of kimchi fermentation prepared with various salts. Korean J. Food Preserv. 12, 395-401.

31. Kim, Y. M., Oh, C. H., In, M. J., and Oh, N. S. (2007) Quality characteristics of fermented beef-rib sauce prepared by Zygosaccharomyces rouxii cultivation. J. Korean Soc. Food Sci. Nutr. 36, 807-812.

32. Korean Food \& Drug Administration (2002) Food Code. Moonyoungsa, Seoul, Korea. p. 220.

33. Laakkonen, E., Wellington, G. H., and Skerbon, J. W. (1970) Low temperature longtime heating of bovine. I. Changes in tenderness, water binding capacity, $\mathrm{pH}$ and amount of watersoluble component. J. Food Sci. 35, 175-177.

34. Lee, J. J., Jung, H. O., and Lee, M. Y. (2011) Development of dduk-galbi added with ripened Korean cabbage kimchi. Korean J. Food Sci. An. 31, 304-310.

35. Lee, J. J., Lee, J. S., Choi, Y. I., and Lee, H. J. (2013) Antioxidant activity of Sansa (Crataegi fructus) and its application to the pork tteokgalbi. Korean J. Food Sci. An. 33, 531-
541.

36. Lee, K. D., Park, J. W., Choi, C. R., Song, H. W., Yun, S. K., Yang, H. C., and Ham, K. S. (2007) Salinity and heavy metal contents of solar salts produced in Jeollanamdo province of Korea. J. Korean Soc. Food Sci. Nutr. 36, 753-758.

37. Lee, K. I., Park, K. Y., and Ahn, H. K. (2011) The anticancer effects of doenjang made with various kinds of salt. The Korean J. Culinary Res. 17, 241-252.

38. Na, B. J. and Ha, S. D. (2009) Effectiveness and safety of salt. Food Sci. Indus. 42, 60-73.

39. Na, J. M., Jin, Y. X., Kim, S. N., Kim, J. B., Cho, Y. S., Kim, K. Y., Kim, H. R., and Kim, S. Y. (2012) Comparison of the quality characteristics of radish by soaking using sun-dried salt and Leuconostoc starter. Korean J. Food Preserv. 19, 951-956.

40. Ruusunen, M., Vainiopää, J., Lyly, M., Lahteenkäli, L., Niemistö, M., Ahvenainen, R., and Puolanne, E. (2005) Reduction of sodium content in meat products: the effect of the formulation in low-sodium ground meat patties. Meat Sci. 69, 53-60.

41. Sheard, P. R., Enser, M., Wood, J. D., Nute, G. R., Gill, P. B., and Richardson, R. I. (2000) Shelf life and quality of pork and pork products with raised n-3 PUFA. Meat Sci. 55, 213-221.

42. Short, E. I. (1954) The estimation of total nitrogen using the Conway micro-diffusion cell. J. Clin. Pathol. 7, 81-83.

43. Song, H. I., Moon, G. I., Moon, Y. H., and Jung, I. C. (2000) Quality and storage stability of hamburger during low temperature storage. Korean J. Food Sci. An. 20, 72-78.

44. Tarrant, P. V., Eikelenboom, G., and Monin, G. (1985) Evaluation and control of meat quality in pigs. Martinus Nijhoff Publishers, 3300 Ad Dordrecht, The Netherlands. pp. 129139.

45. Watanabe, K. and Sato, Y. (1974) Meat flavor. Jpn. J. Zootech. Sci. 45, 113-128.

46. Witte, V. C., Krause, G. F., and Baile, M. E. (1970) A new extraction method for determining 2-thiobarbituric acid values of pork and beef during storage. J. Food Sci. 35, 582-587.

(Received 2014.6.27/Revised 2014.8.8/Accepted 2014.8.12) 